\title{
Praktik Politik Oligarki dan Mobilisasi Sumber Daya Kekuasaan Di Pilkades Desa Sitimerto Pada Tahun 2016
}

\author{
Endik Hidayat ${ }^{1}$, Budi Prasetyo, Setya Yuwana \\ endikhidayat-16@fisip.unair.ac.id, budi.prasetyo@fisip.unair.ac.id, \\ setyayuwana@unesa.ac.id
}

\begin{abstract}
Abstrak
Kemunculan perdebatan tentang pemilihan kepala desa, apakah wujud demokrasi atau bukan demokrasi? Karena dikuasai segelintir orang oligarki telah lama terjadi di kalangan ahli desa. Oleh karena itu, artikel ini bertujuan mengetahui perkembangan model demokrasi dan sumber kekuasaan oligarki di desa Sitimerto Kabupaten Kediri dalam Pilkades serentak tahun 2016 yang lalu. Artikel ini menggunakan pendekatan kualitatif dan mengambil studi kasus pada pemilihan kepala desa Sitimerto, Kecamatan Pagu, Kabupaten Kediri, Propinsi Jawa Timur. Kasus tersebut menarik diteliti karena Pilkades Sitimerto diduga mewakili desa dengan karakter budaya Jawa dan penguasa oligarki cukup kuat. Hasil penelitian membuktikan bahwa sumber daya material masih dominan di dinamika politik desa Sitimerto. Politik uang adalah salah sumber daya material berfungsi mempengaruhi pemilih desa dengan makna beragam. Namun, para oligarki harus juga merangkap sebagai elit untuk dapat mengekploitasi sumber daya non-material untuk lebih menjamin kemenangan di pemilihan kepala desa Sitimerto. Dalam penelitian ini, sumber daya non-material adalah identik dengan sumber kekuasaan Jawa bersifat kekuasaan spiritual atau disebut kesakten.
\end{abstract}

Kata kunci: Kesakten, Oligarki, Pilkades, Politik. Uang

\begin{abstract}
The emergence of a debate about the village head elections, is it a form of democracy or not democracy? Because it is controlled by a handful of oligarchs, it has long occurred among village experts. Therefore, this article aims to find out the development of the democratic model and the source of oligarchic power in Sitimerto village, Kediri regency in the Pilkades 2016. This article uses a qualitative approach and takes a case study on the selection of Sitimerto village heads, Pagu District, Kediri District, East Java Province. The case was interesting because the Sitimerto Pilkades allegedly represented a village with Javanese cultural characters and the oligarchs were quite strong. The results of the study prove that material resources are still dominant in the political dynamics of Sitimerto village. Money politics is a material resource that functions to influence village voters with diverse meanings. However, oligarchs must also become as elites to be able to exploit non-material resources to better guarantee victory in the election of the Sitimerto village head. In this study, nonmaterial resources are identical with Javanese sources of power which are spiritual powers or called kesakten.
\end{abstract}

Keywords: Head of Village Election, Money Politic, Oligarchy, Supernatural Powers

\footnotetext{
${ }^{1}$ Korespondensi: Endik Hidayat. Mahasiswa Program Pascasarjana Doktor Ilmu Sosial Universitas Airlangga. Jl Dharmawangsa Dalam Surabaya. Telp (031) 5034015
} 


\section{Pendahuluan}

Artikel ini berusaha melacak penggunaan dan mobilisasi sumber daya kekuasaan oligarki di pedesaan Jawa. Apakah masih bertumpu kepada sumber daya kekuasaan material, atau sudah berkolaborasi dengan sumber daya kekuasaan lainnya. Karena penguasa oligarki di desa Sitimerto telah membangun dinasti politik keluarga sejak tahun 1998. Sebagai dampak liberalisasi politik di tingkat nasional berimbas kepada politik pedesaan. Apalagi, dalam Undang-Undang Nomor 6 Tahun 2014 Tentang desa membuka kesempatan seluas-luasnya kepada warga desa untuk berkontestasi dalam pemilihan kepala desa serentak. Hal ini memberikan peluang bagi munculnya penguasa oligarki desa yang berkuasa melalui proses demokratisasi seperti pemilihan kepala desa.

Seperti pembahasan penelitian sebelumnya ada pendapat Kroef (1960) bahwa penyelenggaraan pemerintahan desa dan pemilihan kepala desa bukan merupakan praktik demokrasi lebih cenderung oligarki. Karena kepala desa tidak dipilih melainkan ditentukan berdasarkan keturunan, atau kalau dipilih hanya dari kalangan terbatas saja, terutama elit ekonomi yang memiliki aset berupa tanah luas. Rapat-rapat desa sebagai sarana penyampaian aspirasi umpan balik dari bawah ke atas hanya boleh dihadiri kalangan terbatas saja (Yuniningsih, 2016). Sehingga memunculkan kembali sebuah pertanyaan apakah ada proses demokrasi di desa atau kekuasaan segelintir orang yang dominan di desa sebagai aktor oligarki.

Demokrasi pedesaan direbut oleh segelintir oligarki yang dimulai dengan polarisasi kepemilikan tanah yang cukup ekstrem. Faktor pemicunya menurut Robison (1981) pemusatan pemilikan tanah dan perkembangan menuju sistem kerjaupah telah mempertajam pembagian kelas, memperlemah struktur klien-patron. Perkembangan ini didorong oleh pemerintah Orde Baru dengan program Bimas (Bimbangan Massal Swa Sembada Pangan) dan oleh sitstem kredit Inpres (Instruksi Presiden). Lebih lanjut, tampak bahwa pejabat-pejabat pemerintah sendiri, dari kepala desa dan sersan tentara sampai bupati dan pejabat tinggi, tampil menjadi tokoh-tokoh terkemuka dalam pengembangan kelas kulak.

Lanjut, Robison (1981) mengkritik penjelasan dengan perspektif politik kultural. Karena jelas tidaklah cukup untuk dapat memahami ketegangan yang ada antara politik kelas dan politik patronase. Hubungan khusus antara bentuk-bentuk 
politik (kelas atau patronase) dengan tenaga dan hubungan produksi harus juga diselidiki. Disini Robison mengajukan pendapat sebagai berikut: Pertama, bahwa bentuk politik patron-klien tidak menunjukan suatu kehadiran kelas-kelas, tetapi merupakan bentuk dimana kelas-kelas mengadakan hubungan dan mencari peluang gerak dalam kehidupan politik dan ekonomi. Kedua, bahwa politik klien-patron di masyarakat pedesaan dapat berubah menjadi politik kelas bila tuan-tuan mengamankan alat-alat ekonomi untuk meloloskan diri dari hubungan patronase atau bila kaum tani dapat mengamankan alat-alat ekonomi. Ketiga, struktur politik klienpatron adalah yang paling cocok dengan formasi sosial yang didominasi oleh produksi agraris, dimana persetujuan sewa tanah merupakan bentuk dasar hubungan produksi sosial dan dimana kepemilikan telah membawa kehadiran kelas pemilik tanah; hubungan-hubugan demikian cenderung bercerai-berai dengan perluasan hubungan produksi kapitalis.

Penguasa oligarki di pedesaan menyadari bahwa demokrasi dan hubungan patron klien diatas, bisa memunculkan ancaman baru bagi akumulasi kekayaan dan pertahanan kekayaaan. Oligarki merasa gelisah tentang bagaimana kekuasaan demokratis di tangan banyak orang bisa mengancam stratifikasi kelas dengan mengambil dan mendistribusikan kekayaaan dikuasai segelintir orang. Setelah tumbangnya Soeharto tahun 1998, kontestasi kekuasaan pedesaaan merupakan suatu campuran oligarki dan demokrasi yang kompleks. Karena akibat polarisasi kepemilikan tanah ekstrem, kapasitas untuk menggunakan sumber kekayaan secara strategis muncul sebagai salah satu sumber daya kekuasaan paling penting dalam politik desa. Seperti dalam konteks penguasa oligarki desa Sitimerto Haji Mul membangun dinasti politik keluarga selama era desentralisasi. Kebijakan desentraliasi dan otonomi desa telah memberikan peluang bagi munculnya oligarki desa yang berkuasa melalui proses demokratisasi pemilihan kepala desa.

Winters (2014) menjelaskan oligark adalah aktor yang diberdayakan oleh kekayaaan - sumber daya paling menonjol di antara bentuk-bentuk kekuasaan lainnya. Kekayaan jelas paling serba-guna dalam arti mudah diubah menjadi pengejawantahan kekuasaan yang lain. Oligarki berbeda dari kaum elit yang menggunakan pengaruh minoritas mereka berdasarkan sumber daya kekuasaan nonmaterial. Kategori oligark dan elite bisa saling tumpang tindih dengan kekuasaan 
oligarkis berpotensi mengarah kekuasaan elite - begitu pula sebaliknya. Namun, keduanya tidak mesti bertumpang tindih. Banyak oligark hanya memiliki sumber daya material, dan banyak elite tidak pernah menghimpun kekayaan yang mendatangkan kekuasaan.

Dalam kasus Pilkades Sitimerto dilihat dari perspektif oligarki dan elite, aktor oligark berperan sekaligus menjadi elite yang memiliki sumber daya material cukup besar dan sumber daya non-material untuk memenangkan kontestasi politik. Misalnya, pada Pilkades yang lalu hanya dua kandidat yang mampu membagikan politik uang dari kelima calon kepala desa Sitimerto. Yaitu Haji Mul yang mampu memberikan nominal terbesar Rp. 200.000 per orang dan lawannya Hari yang hanya mampu memberikan Rp. 50.000 ribu per orang. Berdasarkan hasil wawancara Haji Mul (2018) menjelaskan menyiapkan dana lima ratusan juta dan berapapun lawan akan menggelontorkan uang, ia mampu menyediakan uang lebih besar lagi.

Sehingga Haji Mul merupakan salah satu oligark terkuat di desa Sitimerto. Haji Mul sebagai puncak oligarki desa Sitimerto berhasil mengakumalasi kekayaan dari bisnis-bisnisnya di bidang pertanian dan peternakan. Haji Mul memilih pemilihan kepala desa sebagai arena unjuk kekuatan ekonomi terhadap lawan-lawan politiknya. Karena Pilkades tidak hanya perebutan kekuasaan dalam rangka suksesi kepemimpinan di desa, akan tetapi lebih daripada itu terutama menyangkut gengsi, harga diri, dan posisi terhormat di mata masyarakat desa. Haji Mul adalah salah satu oligark sekaligus elite di desa Sitimerto. Dinasti kekuasaannya didukung keberhasilan dalam mengelola bisnis pertanian dan peternakan di Kabupaten Kediri. Setelah istrinya berhasil menduduki kursi jabatan kepala desa Sitimerto selama tiga periode (1998-2015). Lantas, pada pemilihan kepala desa tahun 2016 yang lalu mengutus putranya Adit untuk bertarung dalam Pilkades Sitimerto. Pada akhirnya Adit mampu memenangkan pemilihan kepala desa dan mampu mempertahankan dinasti politik keluarga Haji Mul.

Untuk memudahkan melihat kebaruan dan perbedaan tulisan ini dari penelitian sebelumnya, maka dapat dibuat pengelompokan beberapa hasil penelitian tentang desa pasca reformasi menjadi lima kategori. Pertama, dalam penelitian Bambang Kuncoro (2014), yang menekankan hubungan desa dan negara pada masa orde baru dan setelah reformasi. Kedua, dalam penelitian Heru Cahyono (2005) yang 
fokus pada aspek relasi kekuasaan antara kepala desa dan Badan Permusyawaratan Desa (BPD). Ketiga, dalam penelitian Iberamsjah (2002) yang menfokuskan perubahan elit desa dan partisipasinya untuk mempengaruhi kebijakan desa. Keempat, dalam penelitian Syaeful Bahar (2017) yang menganilisis tentang orang kuat lokal desa dan jaringan sosial di pedesaan. Kelima, dalam penelitian Edward Aspinall dan Noor Rohman (2017), yang menfokuskan pada kontestasi politik dalam pemilihan kepala desa.

Bedasarkan pengelompokan fokus studi diatas, tulisan ini identik dengan kategori terakhir. Namun aspek kebaruan tulisan ini, adalah unit analisis teoritis untuk menganalisis bentuk mobilisasi sumber-sumber kekuasaan calon kepala desa bertarung dalam kontestasi politik desa Sitimerto dengan pendekatan kultural (kekuasaan Jawa) dan pendekatan ekonomi politik (oligarki). Karena penelitian tentang desa pasca reformasi belum pernah menggunakan kedua perspektif sekaligus. Tulisan ini juga ingin melihat perbedaan praktik oligarki di tingkat provinsi dan kabupaten/kota dengan tingkat pedesaan. Jika berdasarkan studi Jeffrey Winters (2011) maupun Richard Robison dan Vedi Hadiz (2004) berkesimpulan bahwa politik oligarki dan sumber daya material masih dominan dalam politik nasional dan politik lokal (Provinsi, Kota, dan Kabupaten) di Indonesia. Sebaliknya, tulisan ini mencoba menguji apakah sumber kekuasaan material yang merupakan basis sumber kekuasaan aktor politik oligarki juga dominan saat diterapkan pada konteks pedesaan, atau terdapat faktor lain termasuk diantaranya sumber kekuasaan non-material.

\section{Tinjauan Pustaka.}

\section{Teori Oligarki}

Dari perspektif teoritik Oligarki tidak sama dengan elit. Perbedaan adalah adalah terletak pada sumber daya kekuasaan yang melandasinya dan jangkauan kekuasaan. Menurut Winters $(2011,12)$ dinasti politik biasa (berasal kalangan elite) sumber daya kekuasaannya berasal dari jabatan resmi, kekuasaan pemaksaan, dan kekuasaan mobilisasi. Sedangkan sumber daya kekuasaan oligarki adalah kekuasaan material (uang). Sepanjang seorang elite tidak memiliki atau menguasai sumber daya material maka ia bukanlah oligark. Dengan kata lain tidak semua elite merupakan oligark, sebaliknya semua oligark adalah elite. Dalam konteks penelitian ini, pada 
kasus desa Sitimerto adalah dinasti politik oligarkis, bukan dinasti politik biasa. Ini dikarenakan kekuasaan dinasti politik Haji Mul bersumber dari akumulasi modal primitif dan bertujuan pada sentralisasi ekonomi. Selain itu jangkauan dominasi Haji Mul secara sistematis memenuhi ruang (desa Sitimerto) sehingga usaha untuk independen atau melarikan diri dari dominasi tersebut sangat susah dan memakan biaya politik yang mahal untuk menumbangkan sang oligark saat pemilihan kepala desa.

Salah satu usaha melawan dominasi Haji mul datang dari lawan politik yang juga merupakan pengusaha konveksi yaitu calon Hari. Namun, pertarungan kedua aktor memiliki sumber kekayaaan basis dari oligark tersebut terlihat sangat tidak seimbang dilihat dari kekuatan ekonominya. Hari hanya mampu menyediakan politik uang jauh di bawah nominal yang disebar ke warga desa oleh keluarga Haji Mul, yakni 50 ribu lawan 200 ribu dalam setiap amplop. Sedangkan ketiga calon kepala desa Sitimerto lainnya Basuki, Rohmad, dan Agung cenderung menggunakan sumber kekuasaan non-material yang identik dengan sumber daya seorang elit desa Sitimerto. Ketiga kandidat kepala desa Sitimerto ini mengaku tidak punya dana besar untuk membagikan politik uang.

Mahalnya biaya memenangkan Pilkades diungkap oleh penelitian Apinall dan Rohman (2017) menjelaskan fenomena politik biaya tinggi menyebabkan hanya penduduk desa yang kaya atau aktor oligarki, yang dapat bersaing untuk mendapatkan jabatan kepala desa di dua desa di Jawa Tengah. Sementara itu di Jawa Timur, dinamika politik pemilihan kepala desa membutuhkan biaya tinggi yang dikuasai kelompok kekerasan bejingan dan elite agama kiai juga diungkap oleh Bahar (2017) di daerah Tapal Kuda Kabupaten Bondowoso. Menurut Hadiz (2010:122) pasca berakhirnya rezim otoriter Orde Baru, politik uang - mengambil berbagai bentuk peran - permainan politik di kota maupun desa. Faktanya, pemilihan walikota dan bupati sekarang lebih kompetitif dan berbiaya tinggi. Hal ini tidak mengejutkan sebab keuntungan potensial ekonomi jabatan kepala daerah cukup menggiurkan, seperti peluang untuk membangun infrastuktur kekuasaan personal dan jaringan patronase melalui kontrol pemerintahan lokal dan mesin politik. Kemudian, hal ini tidak hanya disebabkan ambisi politisi lokal untuk bercita-cita karier politik yang lebih tinggi. 
Secara definisi oligarki adalah kekuasaan sekelompok kecil yang berorientasi pada kepentingan pribadi. Definisi ini menegaskan tentang terbatasnya jumlah kepemilikan kekuasaan dan penggunaan kekuasaan yang sasaran utamanya bukanlah orang banyak (masyarakat). Kekuasaan dengan demikian menjadi sesuatu yang "elitis" dan tidak memberikan peluang yang sama bagi setiap orang untuk menikmatinya. Konsep oligarki merujuk kepada proposisi yang sering dikemukakan oleh Robert Michels (1984) dengan teori "iron law of oligharcy" yang mengajukan postulat bahwa oligarki merupakan hukum besi di setiap organisasi. Artinya dalam organisasi, secara alamiah kekuasaan akan jatuh ke tangan segilintir kecil pimpinan dan mendorongnya mmenjadi birokratis bahkan terkadang bersifat konservatif. Sehingga, semakin kompleks suatu organisasi maka cenderung menjadi oligarki.

Perkembangan teori oligarki di Indonesia banyak merujuk pada studi yang dilakukan oleh Richard Robison dan Vedi R. Hadiz, serta Jeffrey A. Winters (Robison dan Hadiz 2005; Hadiz 2010; Winters 2011). Secara garis besar, keduanya melihat bahwa perubahan politik pasca Orde Baru sebagai bagian demokratisasi tidak menyingkirkan kekuasaan oligarki yang telah dibangun sejak tumbuhnya rezim Soeharto. Meskipun demikian, terdapat perbedaan di antara keduanya dalam melihat Oligarki. Kunci keberhasilan reorganisasi oligarki tersebut terletak pada kelenturan jaringan otoritas politik dan kepentingan ekonomi yang menopang dan mencirikan oligarki serta menjalari institusi negara itu sendiri. Salah satu upaya bertahan hidup dari jaringan oligarki Orde Baru dilakukan dengan memanfaatkan ruang yang disediakan desentraliasi (Robison dan Hadiz, 2005). Lanjut Hadiz (2010), dengan didukung kekayaan material yang berlimpah, jaringan oligarki lama ini berusaha tetap menjadi kekuatan dominan di tingkat lokal. Hal itu dilakukan dengan menguasai partai politik, memainkan politik uang dan suap, dan mengerahkan aparat kekerasan non-negara. Bahkan jaringan oligarki tersebut bisa menguasai politik lokal hingga sampai tingkat pedesaaan.

Sementara itu teoritisi oligarki lainnya, Winters (2011) menjelaskan tipologi oligarki yang ada dalam masyarakat. Pertama, oligarki panglima yakni kekuasaan diperoleh melalui peperangan dan terpusat pada individu, pertahanan kekayaan menggunakan paksaan dengan senjata. Kedua, oligarki penguasa kolektif yakni kekuasaan yang diperoleh melalui proses politik dalam suatu lembaga yang 
memiliki norma dan aturan main, pertahanan kekayaan menggunakan kekerasan fisik dan non fisik. Ketiga, oligarki sultanistik yakni kekuasaan diperoleh melalui monopoli kekuasaan pada satu individu, pertahanan kekayaan menggunakan hubungan patronklien dengan penguasa. Keempat, oligarki sipil yakni diperoleh melalui penumpukan kekayaan materiil, memanfaatan negara sebagai basis dalam mempertahankan pendapatan. Kempat tipologi tersebut digunakan Winters dalam upaya menjelaskan praktik oligarki di tingkat nasional.

Berkaitan dengan Pilkades dan Politik Lokal, Hadiz (2010) menjelaskan pola-pola operasionalisasi oligarki di tingkat lokal (Tulisan ini lokus di tingkat desa) pasca Orde Baru ditandai oleh beberapa ciri mendasar. Pertama, jejaring kekuasaan oligarki bersifat predatoris yang menggunakan kekuasaan dan institusi negara untuk akumulasi kekayaan dan kekuasaan individu. Kedua, koalisi yang cair dan tidak pernah stabil di tingkat lokal. Koalisi yang cair itu didasari pragmatisme untuk mendapatkan sumber daya material di tingkat lokal. Dari perebutan sumber daya itulah kemudian koalisi dan konflik elite di tingkat lokal terbentuk. Ketiga, pola jaringan patronase di antara pejabat pemerintahan, pengusaha lokal, organisasi preman, dan aparat keamanan. Keempat, penggunaan politik uang dalam jumlah yang besar untuk memenangkan sumber daya publik. Kelima, penggunaan kekuatan koersif non-negara (organisasi preman) untuk mengamankan kepentingan ekonomi politik. Keenam, praktik di atas didukung dengan lemahnya kekuatan massa atau civil society di luar jejaring oligarki (Ananta, 2016). Sedangkan konsep oligarki Winters, Robison maupun Hadiz berangkat dari konsep pertahanan kekayaan 'wealth defense'.

Kontestasi politik di desa Sitimerto berangkat dari perpaduan antara bertahan dinasti keluarga kepala desa 'tuan tanah lama' yang disebut elite desa dan kebangkitan kelompok ekonomi pasca reformasi yang bermutasi menjadi aktor oligark. Di desa Sitimerto, terlihat dominasi politik uang oleh aktor oligarki keluarga Haji Mul yang mampu mempertahankan kekuasaan dengan menunjuk putranya Adit untuk meneruskan kepemimpinan ibunya periode sebelumnya (1998-2015). Sehingga jabatan kepala desa masih dipandang sebagai posisi strategis (hak tanah bengkok) dan gengsi sosial bagi keluarga Haji Mul. Pertarungan kekuasaan Pilkades di antara calon kepala desa Sitimerto yang berasal dari aktor oligark melawan aktor elite desa, terlihat dari penggunaan sumber daya kekuasaan dalam mempengaruhi pemilih desa 
Sitimerto. Karena aktor oligarki lebih mengandalkan keunggulan sumber daya material, sebaliknya aktor elite desa lebih mengandalkan sumber daya non-material yang dalam artikel ini disebut sumber kekuasaan spiritual.

\section{Teori Elit}

Berkaitan dengan teori klasik Vilfredo Pareto termasuk tokoh awal yang menggunakan dan menjelaskan konsep elit. Pareto membedakan antara elit yang memerintah (governing elite) yang terdiri dari individu-individu yang secara langsung ataupun tidak langsung memainkan peranan penting dalam pemerintahan, dan elit yang tidak memerintah (non-governing elite). Jadi, terdapat dua lapisan dalam masyarakat, yakni lapisan rendah (non-elit), dan lapisan yang tinggi (elite) yang terdiri dari elit yang memerintah dan elit yang tidak memerintah (SP Varma, 2007:202).

Teoretisi elit lainnya yang termasuk modern, Keller (1995) yang banyak membahas elit berkuasa dan elit strategis menyatakan bahwa di masyarakat Amerika di samping adanya ruling elite (kelompok elit yang memegang kekuasaan), terdapat suatu kelompok elit yang disebut strategic elite (elit penentu). Menurutnya, apabila ada yang menilai dan mengerti the ruling class, dia harus mampu menilai juga beyond the ruling class yaitu the strategic elites di bidang ekonomi, politik, agama, ilmu pengetahuan, komunikasi massa dan sebagainya. Dasar yang menjadi pertimbangan adalah pengaruh yang besar terhadap tokoh-tokoh di bidang politik dan pemerintahan meskipun strategic elite berada di sektor nonpemerintahan. Hampir sama dengan pandapat Mills (1956), Keller juga mengemukakan bahwa apabila strategic elite masuk ke dalam kelompok berkuasa, maka elit tersebut dimasukan di dalam the ruling eliters. Selanjutnya, apabila sudah tidak berada dalam kelompok yang memerintah, mereka kembali ke dalam strategic elites.

Pembahasan diatas adalah studi elite yang berkembang di Barat. Selanjutnya akan ada pembahasan tentang perkembangan studi elite yang relevan dengan penelitian ini pada masyarakat pedesaan di Indonesia. Dimulai dengan studi elite desa dalam perubahan politik pasca reformasi, Iberamsjah (2002) menemukan elite desa baru yakni Badan Permusyawaratan Desa (BPD), yang mamu mengimbangi kekusaaan elit desa lama yaitu kepala desa. Studi elite desa lainnya oleh Pribadi (2015) di pedesaan Madura membagi elit desa menjadi tiga kategori. Pertama, elit formal 
desa meliputi; kepala desa (klebun) dan pamong desa. Kedua, elit agama diwakili oleh tokoh agama kiai. Ketiga, elit informal desa yang identik dengan profesi premanisme dengan sumber kekuasaan kekerasan disebut blater di Madura. Terakhir studi elit desa Aspinall dan Rohman (2017) yang menjelaskan dalam dinamika politik di pedesaan setelah reformasi ditandai kebangkitan para elite ekonomi desa yang mampu mempengaruhi pembuatan suatu kebijakan desa. Oleh karena itu faktor kekayaan merupakan komponen utama legitimasi status sebagai elite desa. Hal ini mendorong elite ekonomi desa untuk bertarung memperebutkan jabatan elite formal desa dalam pemilihan kepala desa. Karena jabatan sebagai kepala desa merupakan wujud pertarungan pengaruh untuk memperkuat legitimasi sebagai elit ekonomi sekaligus elit forma desa.

\section{Teori Sumber Daya Kekuasaan}

Surbakti (2010, 72) menjelaskan seseorang dipandang mempunyai kekuasaan potensial apabila dia memiliki sumber-sumber kekuasaan, seperti kekayaan, tanah, senjata, pengetahuan dan informasi, popularitas, status sosial yang tinggi, massa yang terorganisasi, dan jabatan. Sebaliknya, seseorang dipandang memiliki kekuasaan aktual apabila dia telah menggunakan sumber-sumber yang dimilikinya ke dalam kegiatan politik secara efektif. Sehingga perbedaan kekuasaan potensial dengan kekuasaan aktual terletak pada penggunaan sumber-sumber secara efektif untuk mempengaruhi proses politik.

Sementara itu, Andrain (1992, 132) mendifinisikan kekuasaan sebagai penggunaan sejumlah sumber daya (aset, kemampuan) untuk memperoleh kepatuhan (tingkah laku menyesuaikan orang lain. Sumber daya kekuasaan itu terdiri atas sumber daya fisik, ekonomi, normatif, personal, dan keahlian. Pertama, yang termasuk sumber daya kekuasaan fisik adalah senjata, bom, penjara dan aparat yang menggunakan senjata. Kedua, sumber kekuasaan ekonomi berupa kekayaan (uang, emas, tanah), pendapatan, dan kontrol terhadap barang dan jasa. Ketiga, sumber kekuasaan normatif adalah moralitas, kebenaran, tradisi, dan religius. Misalnya, pemimpin agama atau pemimpin suku ditaati oleh masyarakat bukan karena senjata atau kekayaan yang dimilikinya, tapi berdasarkan agama dan adat. Keempat, sumber daya personal yakni kharisma pribadi, daya tarik, dan popularitas. Sebagai contoh, penampilan bintang 
film terkenal, pemain sepak bola cemerlang, penyanyi yang dipuja, ataupun pemimpin kharismatik. Kelima, sumber daya keahlian yang berasal pengetahuan, intelegensia, dan keahlian teknis.

Dengan penekanan pada kapasitas, teori sumber daya kekuasaan mengandaikan bahwa pada waktu tertentu setiap anggota masyarakat memiliki suatu parameter kekuasaan mulai dari yang sangat kecil (hampir nol) hingga sangat besar. Teoritisi lainnya Winters (2011:15-20) menawarkan lima sumber daya kekuasaan individual meliputi; hak politik formal, jabatan resmi (baik di dalam maupun di luar pemerintahan), kuasa pemaksaan (coercive power), kekuatan mobilisasi, (mobilizational power), dan kekuasaan material (material power). Empat sumber daya yang pertama, ketika didistribusikan dengan cara ekslusif atau terkonsentrasi, adalah dasar yang umumnya dikenal sebagai politik "elite." Sumber daya yang terakhir, kekuasaan material, adalah basis oligarki. Kelima sumber daya ada di Indonesia dan masingmasing memainkan peran politik.

Pembahasan tentang sumber kekuasaan oligarki desa ini dimaksudkan untuk mengungkapkan apa yang menjadi landasan terbentuknya pengaruh dari aktor oligark desa. Kuatnya pengaruh aktor oligark desa berhubungan dengan kepemilikan sumber daya material dengan peranan untuk membeli suara pemilih desa (money politic) saat Pilkades Sitimerto. Sebaliknya jika melihat sumber daya elite desa bisa menggunakan sumber daya non-material untuk kepentingan Pilkades, yakni dalam artikel ini identik dengan sumber kekuasaan spiritual (Kekuasaan Jawa). Misalnya, Iberamsjah $(2002,21)$ memberi gambaran empiris tentang sumber daya kekuasaan di elite pedesaan terbagi menjadi empat kategori. Pertama, elite agama mampu bertahan dengan sumber ilmu dan pengetahuan agama Islam. Kedua, elite birokrasi dengan sumber kekuasaan jabatan di pemerintahan. Ketiga, elite cendikiawan dengan sumber kekuasaan pendidikan ilmu pengetahuan. Keempat, elite ekonomi dengan sumber kekuasaan aset kekayaan. Sehingga dalam kontestasi politik desa oligark bisa sekaligus menjadi elite. Karena perpaduan penggunaan sumber kekuasaan material dan sumber kekuasaan spiritual dapat menjadikan keluarga incumbent Haji Mul kembali menduduki posisi kepala desa.

Konsep sumber kekuasaan diatas identik dengan Barat. Sebagai konsep sumber kekuasaan berasal dari luar, konsep ini tidak dapat menjelaskan secara tuntas 
gejala politik kekuasaan dalam politik Indonesia. Seperti karakteristik sumber daya kekuasan spiritual menurut budaya Jawa pemikiran Anderson justru bertolak belakang dengan gambaran kekuasaan material teoritis Barat atau oligarki. Menurut budaya Jawa, sumber-sumber kekuasaan diperoleh dengan cara bertapa dan praktek yoga, seperti berpuasa, berjalan tanpa tidur, meditasi, dan tak melakukan hubungan kelamin dalam jangka waktu tertentu. Selain bertapa dan praktek yoga, kekuasaan dapat juga diperoleh dengan mengadakan upacara-upacara kebesaran yang melibatkan banyak orang, objek-objek yang mengandung "kekuatan", dan simbolsimbol yang mengandung pengertian mistis. Termasuk ke dalam kategori yang terakhir ini berupa upacara-upacara kenegaraan, dan pementasan wayang dengan lakon terpilih. Masih ada cara lain, yaitu dengan mengumpulkan benda-benda, seperti keris, gamelan, kereta kencana, payung kebesaran, dan barang-barang pusaka (regalia) lainnya, atau mereka yang dipandang mempunyai kesakten, seperti pelawak, orang kasim, orang kerdil, peramal, dukun, resi, dan mereka yang dianggap memiliki kelebihan (Surbakti, 2010: 102).

Dari sumber-dumber daya kekuasaan yang dikemukakan oleh Andrain, Winters dan Anderson, maka dapat dijelaskan bahwa aktor oligark berperan sekaligus sebagai elite desa memiliki beberapa sumber daya kekuasaan utama. Di antaranya sumber daya kekayaan, pendapatan, bisnis, dan kontrol terhadap barang dan jasa. Namun, ternyata mobilisasi sumber daya material belum menjamin kemenangan dalam pemilihan kepala desa. Dalam kontestasi politik desa, seorang oligark desa dapat sekaligus sebagai elit desa untuk memenangkan pemilihan kepala desa, dengan mengekploitasi sumber kekuasaan spiritual, yang dalam penelitian ini identik dengan simbol-simbol kekuasaan menurut budaya Jawa. Pemilihan kepala desa Sitimerto menjadi salah satu lokasi penelitian memiliki penghargaan yang sangat tinggi pada kepribadian kandidat pemimpin desa, serta kemampuan aktor politik dalam memecahkan masalah-masalah kemasyarakatan di desa. Dengan demikian, oligark yang berbasis kekuasaan material dan kekuasaan spiritual dapat menjadi wacana teoritis baru sumber kekuasaan di politik lokal di Indonesia. 


\section{Pilkades dan Demokrasi Desa}

Di pedesaan Jawa, demokrasi dilaksanakan dengan keikutsertaan warga desa dalam proses pengambilan keputusan, yang pada prinsipnya dinamakan musyawarah. Keikutsertaan ini dimaksudkan untuk membina suatu persetujuan dalam masyarakat desa melalui konsultasi, dengan lebih sedikit konflik daripada diatur dengan pemungutan suara terbanyak. Wujud partisipasi masyarakat dengan semangat musyawarah mufakat pernah menjadi dasar dari demokrasi desa, sebelum diperkenalkan pengembilan keputusan dengan sistem pemungutan suara di pedesaan Jawa. Salah satu wujud praktik demokrasi desa yang sampai sekarang bertahan adalah dalam pemilihan kepala desa.

Di kalangan ilmuwan ahli desa terdapat perdebatan teoritik mengenai ada atau tidak proses demokrasi dalam politik pedesaan. Di satu pihak pendapat Koef (1960) mengatakan bahwa penyelenggaraan pemerintahan desa termasuk di dalamnya proses seleksi kepemimpinan melalui pemilihan kepala desa bukanlah praktik demokrasi (Yuniningsih, 2016). Sedangkan di pihak lainnya mengatakan pemerintahan desa dengan proses pemilihan kepemimpinan kepala desa merupakan praktik nyata dari demokrasi langsung. Pandangan ini dianut oleh sebagaian pemikirpemikir ahli desa Indonesia. Misalnya dalam hal perekrutan perangkat desa Faturahman (2018) menjelaskan perekrutan yang selektif dan terbuka merupakan syarat bahwa kehidupan demokrasi dalam penyelenggaraan pemerintahan di tingkat desa mutlak diperlukan untuk menjaga keharmonisan sosial. Perilaku demokratis berdasarkan kompromi desa dapat dijadikan rujukan untuk perekrutan pegawai di sektor pemerintah pusat dan daerah.

Perdebatan terkait apakah dinamika politik dalam proses pemilihan kepala desa merupakan bagian dari perwujudan nilai-nilai demokrasi atau bukan dapat merujuk pada lima kriteria ideal demokrasi dari Robert Dahl (1989). Pertama, partisipasi efektif; adanya kesempatan yang sama dan setara untuk berpatisipasi. Kedua, kesetaraan pilihan; adanya jaminan penilaian setiap pilihan dihitung setara. Ketiga, pemahaman yang memadai; adanya pemahaman yang memadai untuk menemukan dan menentukan pilihan terbaik. Keempat, kontrol terhadap agenda; kesempatan untuk menentukan masalah politik. Kelima, inklusif dan tidak adanya pengecualian untuk seluruh warga/pemilih (Yuniningsih, 2016: 238). 
Studi Yuniningsih (2016) tentang praktik Pilkades di tiga desa Jawa Barat sebagian telah memenuhi kriteria demokrasi, namun sebagian lainnya masih belum terpenuhi. Sehingga konsep demokrasi dimaknai berbeda-beda dalam praktik masingmasing Pilkades yang diteliti. Kembali ke fokus desa Sitimerto, pertarungan kekuasaan antar aktor-aktor politik berasal dari oligark dan elite yang terjadi di Pilkades Sitimerto, mengakibatkan dua kriteria demokrasi berhasil terpenuhi adalah partisipasi efektif dan kontrol terhadap agenda. Sedangkan tiga kriteria lain yaitu kesetaraan pilihan, pemahaman yang memadai, dan inklusif masih belum sepenuhnya tercapai dalam Pilkadesa yang lalu tahun 2016.

\section{Kerangka Konseptual}

Analisis pada penelitian ini berdasarkan konsep dan teori oligarki, elite, sumber daya kekuasaan dan demokrasi. Terdapat dua teori utama yang digunakan kekuasaan oligarki dan elite. Pandangan teoritik sumber daya kekuasaan Jawa Anderson (1972) dan Winters (2011), Robison maupun Hadiz (2005). Dari berbagai penelitian terdahulu dan teori yang dipaparkan dalam studi ini maka kerangka analisis penulis disampaikan pada Gambar 1.

Artikel ini menggunakan pendekatan kualitatif dan mengambil studi kasus pada pemilihan kepala desa Sitimerto, Kecamatan Pagu, Kabupaten Kediri, Propinsi Jawa Timur. Kasus tersebut menarik diteliti karena Pilkades Sitimerto diduga mewakili desa dengan karakter dinasti oligarki kuat. Hal menarik terjadi adalah para calon kepala desa berasal dari kalangan oligark dan elite desa. Misalnya, hanya ada dua calon yang mengandalkan sumber kekuasaan material identik basis kekuasaan oligarki yakni keluarga incumbent Adit dan Hari. Sementara tiga calon yang lain mengaku tidak punya sumber daya material yang besar dan hanya mengandalkan sumber daya non-matarial. Sehingga penelitian diskriptif berusaha menggambarkan dinamika pemilihan kepala desa Sitimerto tahun 2016. 


\section{Gambar 1. Kerangka Konseptual}

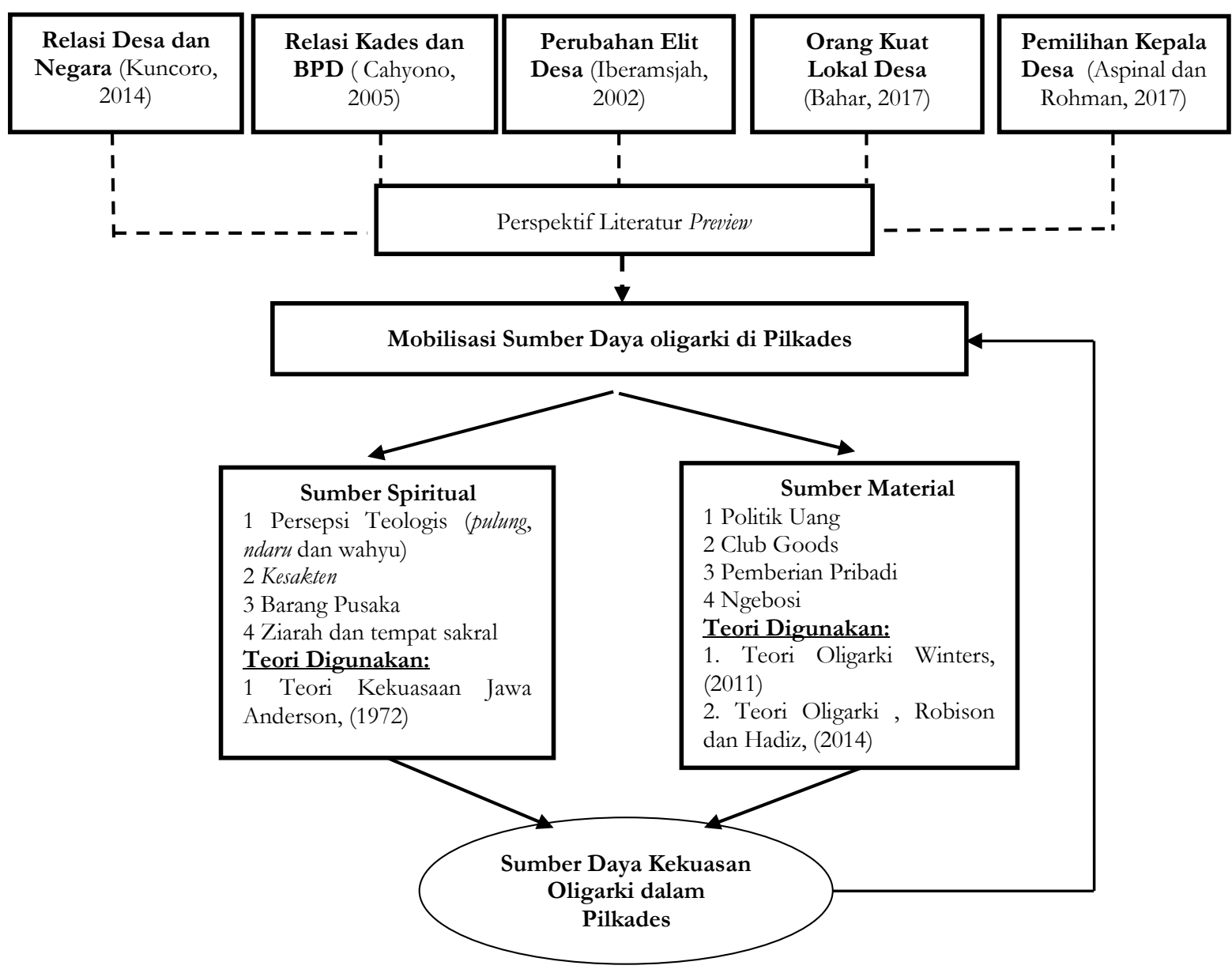

\section{Metode}

Studi ini bersifat diskriptif analisis, bertujuan memberi gambaran yang lebih detail mengenai suatu gejala atau fenomena. Karakteristik diskripsi mendalam ini sesuai dengan difinisi penelitian kualitatif oleh Norman K Denzin (2009) metode kualitatif menekankan pada proses dan makna yang tidak dikaji secara ketat atau belum diukur dari sisi kuantitas, jumlah, intensitas atau frekuensi, dan menekankan pada sifat realitas yang terbangun secara sosial, hubungan erat antara peneliti dan subjek yang diteliti.

Teknik yang dipergunakan dalam pengumpulan data adalah menggunakan teknik data deskriptif sebagaimana digambarkan tersebut adalah teknik observasi, wawancara mendalam, dokumentasi, dan Focus Group Discussion (FGD). Penilitian ini merupakan model post factum, yakni penelitian yang analisisnya dilakukan 
setelah pemilihan kepala desa usai. Karena wawancara mendalam dilakukan setelah Pilkades Sitimerto 28 Desember 2016. Strategi wawancara dilakukan dengan melibatkan beberapa informan sebagai subjek penelitian utama, yaitu para calon kepala desa yang berkompetisi dalam Pilkades, dan para tokoh masyarakat yang juga mungkin berasal dari keluarga para kandidat kepala desa yang bertarung di Pilkades. Hasil analisis secara kualitatif kemudian diuraikan secara deskriptif berupa sajian kata-kata melalui urutan penyajian kondisi lapangan dalam bentuk transkrip wawancara, dan dilanjutkan dengan penarikan kesimpulan untuk memperoleh hasil akhir penelitian.

\section{Hasil dan Pembahasan}

\section{Sumber Kekuasaan Oligarki dan Elite Desa}

Sebagaimana telah dikemukakan sebelumnya bahwa di pedesaaan Kediri selain kelompok elite desa yang memiliki pengaruh di masyarakat, juga terdapat kelompok oligark yang juga memilik i pengaruh di masyarakat pedesaan Jawa. Oligarki dibedakan dari elite desa biasa atas dua hal. Pertama, menyangkut jenis sumber daya kekuasaan apa yang menopang kelompok oligarki. Kedua, jangkauan kekuasaan minoritas tersebut. Menurut Winters (2011) elite dan oligark sama-sama menggunakan kekuasaan dan pengaruh minoritas. Namun kemampuan mereka melakukan itu berdasar pada jenis kekuasaan yang berbeda. Kenyataan ini telah menimbulkan hasil politik yang berbeda-beda sekali. Salah satu perbedaan paling dasar adalah bahwa hampir semua bentuk pengaruh minoritas elite telah ditentang melalui pergulatan dan perubahan demokratis, sementara kekuasaan oligarkis, karena hakekatnya beda, belum. Para ahli teori elite tak punya penjelasan mengapa kekuasaan politik mahabesar oligark sangat kebal terhadap semua tantangan dari demokrasi kecuali yang paling radikal - yang justru sengaja dicegah oleh rancangan demokrasi yang ada. Oligark bisa punya bentuk kekuasaan elite di atas bercampur dengan dasar material. Jika demikian maka oligark bisa sekaligus menjadi elite. Tapi elite tak bisa menjadi oligark kalau tidak memiliki dan menggunakan sendiri kekuasaan material yang besar.

Ditinjau dari jenis sumber daya kekuasaan elite bisa bermacam-macam diantaranya; hak politik formal, kekuasaan pemaksa, jabatan resmi, dan kekuasaan 
mobilisasi. Sedangkan sumber daya kekuasaan oligarki adalah keunggulan kekuasaan material. Konsekuensinya sepanjang tidak memiliki kekuasaan material, seorang elite tidak pernah menjadi oligark. Sebaliknya seorang oligark selalu sekaligus menjadi elite. Sehingga sumber daya material oligark adalah sumber daya yang harus tersedia dalam jumlah cukup besar dan dapat digunakan untuk kontestasi politik bersifat kepentingan politik pribadi. Sejauh ini hasil analitis terpenting pendekatan sumber daya kekuasaan adalah mempertajam pembedaan antara bentuk kekuasaan minoritas elite dan oligarkis. Keempat sumber daya kekuasaan yang disebut pertama, ketika dipegang individu secara terkonsentrasi dan eksklusif, menghasilkan elite. Hanya yang terakhir, kekuasaan material, yang menghasilkan oligark dan oligarki (Winters, 2011: 19). Dengan itu, dalam konteks pedesaan, hanya calon kepala desa yang menguasai dan mengendalikan konsentrasi besar sumber daya material saja yang bisa disebut oligark.

Hampir mayoritas calon kepala desa Sitimerto menggunakan sumber daya material pada pemilihan kepala desa serentak tahun 2016. Sehingga potensi penggunaan uang sebagai pelekat kepentingan, sangat mungkin terjadi dalam berbagai modus yang sulit dijabarkan sebagai praktik money politics. Klaim bernuansa politik mencerminkan tujuan mendapatkan jabatan politik kepala desa untuk mengimbangi biaya dan sumber daya material uang telah dikeluarkan dalam partisipasi calon kepala desa berbagai kegiatan Pilkades. Pada masyarakat desa, uang adalah media yang signifikan mampu mengendalikan energi dan sumber daya lain. Karakternya khusus yang membedakan uang dibandingkan sumber daya lainnya adalah sifatnya yang likuid, transferrable (mudah dipindahkan), dan tidak beridentitas.

Pada pemilihan kepala desa Sitimerto yang lalu dari total lima calon yang mendaftar, hanya terdapat dua calon kepala desa yang siap modal uang berkontestasi dalam Pilkades yakni Adit dan Hari. Sementara itu, tiga kandidat lainnya mengaku hanya coba-coba maju di Pilkades Sitimerto, jadi tidak membagikan uang saat Pilkades kemarin. Adit (2017) mengaku politik uang sebagai ganti uang hadir bagi masyarakat desa yang datang ke tempat pemungutan suara. Ditambah dengan pembagian sembako yang pembagian melalui rumah-rumah warga desa saat masa kampanye menjelang pemilihan kepala desa. Orang tua Adit selaku pemodal Haji Mul (2018) menerangkan bahwa berapa pun nilai politik uang yang disebar lawan 
politiknya untuk membeli suara pemilih desa Sitimerto. Ia sanggup menyediakan lebih besar, demi putranya terpilih sebagai kepala desa menggantikan ibunya yang telah menjabat dua periode sebelumnya (1998-2015). Ia mengaku menghabiskan uang sebesar lima ratus juta rupiah (Rp. 500.000.000) untuk mengalahkan lawan-lawan politiknya di Pilkades tahun 2016 yang lalu.

Kondisi tingginya minat masyarakat desa Sitimerto untuk berebut jabatan kepala desa, menyebabkan tingkat kompetisi antar calon kepala desa Sitimerto cukup tinggi. Akibat kontestasi cukup ketat, terdapat beberapa model strategi pemenangan yang digunakan calon kepala desa Sitimerto untuk mempengaruhi pemilih desa. Sumber daya yang digunakan untuk proses mobilisasi pemilih tersebut dapat dibagi menjadi sumber kekuasaan material dan sumber kekuasaan spiritual. Maka untuk mencermati seluruh data yang dikumpulkan dari penelitian lapangan tentang sarana sumber daya kekuasaan dalam proses pengaruh dalam pemilihan kepala desa oleh kelima calon kepala desa Sitimerto dapat terurai dalam paparan masing-masing kandidat bertarung dalam pemilihan kepala desa Sitimerto sebagai berikut ini.

Pertama, calon kepala desa Agung, merupakan salah satu kepala desa yang berprofesi sebagai pedagang soto, yang dinilai kurang serius dalam pemilihan kepala desa yang lalu. Karena keterbatasan sumber daya material, Agung (2017) mengaku lebih senang menggunakan jasa dukun dengan alasan lebih praktis. Namun, ia tidak percaya dengan barang pusaka yang diberikan dukun jawa tersebut. Dari hasil wawancara ia hanya mengeluarkan dana sedikit untuk kegiatan ngebosi yakni berupa menyediakan makanan dan minuman di rumah sang calon kepala desa, malam menjelang pemilihan kepala desa. Ia juga mengaku sebagai mantan pengurus partai bulan bintang ranting Kecamatan Pagu Kabupaten Kediri.

Kedua, calon kepala desa Hari, salah satu kepala desa yang berprofesi sebagai pengusaha konveksi. Ia dinilai kelompok incumbent sebagai penantang paling serius daripada tiga calon yang lain. Dengan kekuatan sumber daya materialnya yang berasal dari usaha konveksinya dan investor politiknya. Hari (2017) mampu membagikan politik uang sebesar 50ribu per orang untuk shodaqoh, membagikan barang sembako, dan ngebosi acara makan-makan di rumah menjelang pemilihan. Sedangkan sumber daya kekuasaan spiritual juga digunakan untuk memobilisasi pemilih desa. Misalnya, mengadakan acara slametan di makam pendiri desa. selain itu, 
untuk menambah kepercayaan diri maju Pilkades, maka menggunakan jasa konsultan spiritual pituo dari kalangan kiai. Berdasarkan hasil wawancara Hari juga menyimpan benda pusaka berupa batu untuk melindungi diri dari serangan gaib lawan, dan terakhir ia merupakan salah satu calon kepala desa Sitimerto yang mempunyai keahlian sendiri dalam mempraktikan sistem hitungan Jawa dalam kehidupan seharihari, yang biasa disebut nagodino (Hari, 2017).

Ketiga, calon kepala desa Basuki, salah satu calon kepala desa yang berprofesi sebagai buruh. Calon kepala desa yang cukup serius mempersiapkan diri dalam menghadapi Pilkades. berdasarkan hasil wawancara bentuk strategi politiknya adalah ngebosi dengan membayari (bisa juga memborong) makan di warung-warung desa. Sehingga menghabiskan banyak sumber daya material, variasi sumber daya material yang lain adalah dalam bentuk club goods kepada kelompok pemuda dan komunitas kesenian jaranan di desa (Basuki, 2017). Sedangkan untuk sumber daya spiritual yang digunakan dalam cukup variatif. Basuki (2017) menerangkan berbagai macam mobilisasi sumber daya spiritual mulai dari yang identik dengan kekuasaan diantaranya; acara slametan di makam pendiri desa, menyimpan benda pusaka berupa keris dan wesi aji, keyakinan akan pulung sebagai tanda kekuasaan berupa mimpi bertemu dengan pendiri desa Sitimerto, laku ngelmu yakni bertapa hampir seminggu di pundhen pendiri desa dan petilasan Joyoboyo, dan terakhir mengambil jasa sepuluh pitou berasal dukun Jawa di Kabupaten Kediri dan Kabupaten Tulungagung, untuk membantu proses pemenangan dan meningkatkan kepercayaan diri dalam menghadapi Pilkades Sitimerto.

Keempat, calon kepala desa pertahanan Adit, merupakan putra dari kepala desa sebelumnya berasal dari keluarga kaya. Calon kepala desa paling besar sumber daya material berasal dari keluarga oligarki atau incumbent. Adit (2017) menjelaskan mampu membagikan politik uang paling besar yakni 200ribu per orang, ditambah lagi dalam bentuk pemberian barang sembako untuk setiap individu. Variasi strategi berbasis sumber daya material lainnya adalah dalam bentuk club goods untuk komunitas masjid bentuknya sumbangan pembangunan, makanan takjil, dan bantuan lain untuk kelompok pengajian masjid. Untuk menambah informasi berdarkan hasil wawancara dengan orang tua Adit. Yakni Haji Mul (2018) menjelaskan secara khusus pemberian sangu barang-barang individu (individual gift) dan barang-barang kelompok 
(club goods) yang dibagikan kepada komunitas-komunitas desa. Untuk komunitas pemuda desa disediakan rokok, kopi, dan nasi bungkus saat begadang ronda malam menjelang malam pemilihan. Sedangkan pada saat yang sama juga disediakan berbagai macam makanan dan minuman di rumah kandidat tersebut yang identik sebagai praktik ngebosi.

Karena Adit didukung juga sumber daya material (keluarga Haji Mul) dampaknya adalah kuatnya pengaruh terhadap jaringan birokrasi desa yang pada periode sebelumnya sudah sangat loyal dengan keluarga pertahanan (kepala desa periode sebelumnya adalah orang tua Adit yakni Tuti). Pada sisi lain, berdasarkan hasil wawancara sumber daya spiritual yang kemarin dipraktikan adalah acara slametan di makam pendiri desa, jasa seorang pituo dari golongan kiai yang sudah dianggap cocok dengan keluarga, keyakinan akan pulung pada posisi letak rumah, termasuk keluarga Adit adalah keturunan lurah atau trah kepala desa (Adit, 2018). Terakhir sumber daya spiritual lainnya berdasarkan pengakuan orang tua Adit, yakni Haji Mul (2018) menerangkan mempunyai keahlian dalam sistem hitungan Jawa saat menghadapi peristiwa-peristiwa penting dalam hidup termasuk pemilihan kepala desa tahun 2016 yang lalu.

Kelima, calon kepala desa Rohmad, berasal dari kalangan petani. Pada saat Pilkades yang lalu, Rohmad (2017) menjelasakan hanya coba-coba saja untuk maju di Pilkades terlihat kurang begitu serius. Pada saat wawancara mengaku hanya menghabiskan dana 3 juta untuk kegiatan ngebosi yakni menyediakan makanan dan minuman di rumah kandidat menjelang hari pencoblosan. Sedangkan dari sumber kekuasaan spiritual yang dipraktikan adalah menyimpan benda pusaka berupa batu merah delima yang digunakan untuk berjaga dari serangan gaib lawan politik ketika pemilihan kepala desa yang lalu. Rohmad merupakan salah satu keturunan lurah atau trah kepala desa yang mungkin bisa mempengaruhi pemilih desa. karena kebaikan orang tuanya dulu saat memimpin desa Sitimerto. Ia termasuk calon kepala desa yang mempunyai jumlah anggota keluarga terbesar di desa Sitimerto. Namun, kenyataannya tidak mampu secara signifikan meningkatkan jumlah perolehan suara pada Pilkades tahun 2016 yang lalu (Rohmad,2017). 
Berdasarkan pengakuan para calon kepala desa Sitimerto diatas, bentuk kepemilikan sumber-sumber kekuasaan dapat dilihat dalam bentuk matriks di bawah ini.

Tabel 1. Sumber Daya Kekuasaan Calon Pilkades Sitimerto

\begin{tabular}{|c|c|c|c|}
\hline \multirow{2}{*}{$\begin{array}{l}\text { No. } \\
\text { Urut }\end{array}$} & \multirow{2}{*}{$\begin{array}{l}\text { Nama Calon } \\
\text { Kepala Desa }\end{array}$} & \multicolumn{2}{|c|}{ Konfigurasi Sumber Kekuasaan } \\
\hline & & Material & Spiritual \\
\hline 1 & Agung & 1 makan-minum gratis di rumahnya & 1 Jasa pitou dari dukun \\
\hline 2 & Hari & $\begin{array}{l}1 \text { Politik Uang Rp. } 50.000 \\
2 \text { Barang Sembako } \\
3 \text { Makan-Minum di rumahnya }\end{array}$ & $\begin{array}{l}1 \text { Acara slametan di pundhen } \\
\text { pendiri desa } \\
2 \text { Jasa pitou dari kiai } \\
3 \text { Benda Pusaka (batu ari-ari) } \\
4 \text { hitungan Jawa (nogodino) }\end{array}$ \\
\hline 3 & Basuki & $\begin{array}{l}1 \text { makan-minum gratis di rumahnya } \\
\text { dan warung sekitar desa } \\
2 \text { Club Good sumbangan barang } \\
\text { kelompok di desa (kesenian jaranan) }\end{array}$ & $\begin{array}{l}1 \text { Acara slametan di pundhen } \\
\text { pendiri desa } \\
2 \text { Jasa pitou dari dukun } \\
3 \text { Benda Pusaka keris, jimat } \\
\text { besi kuning dsb } \\
4 \text { percaya pulung } \\
5 \text { pengguna hitungan Jawa } \\
6 \text { semedi tempat sakral }\end{array}$ \\
\hline 4 & $\begin{array}{l}\text { Adit/Haji } \\
\text { Mul }\end{array}$ & $\begin{array}{l}1 \text { Politik Uuang Rp. } 200.000 \\
2 \text { Barang sembako } \\
3 \text { Makan-minum gratis di pos ronda } \\
\text { dan rumah kandidat } \\
4 \text { Club Goods kelompok pemuda dan } \\
\text { kelompok agama berupa } \\
\text { sumbangan pembangunan masjid } \\
\text { dan takjil, dan lain untuk pengaiian. } \\
5 \text { Jaringan Birokrasi desa solid } \\
\text { mendukung incumbent }\end{array}$ & $\begin{array}{l}1 \text { Slametan di pundhen desa } \\
2 \text { Pitou jasa kiai } \\
3 \text { Pulung ada, keyakinan } \\
\text { posisi letak rumah } \\
4 \text { Hitungan Jawa dari orang } \\
\text { tua Haji Mul } \\
5 \text { keturunan lurah dari kakek }\end{array}$ \\
\hline 5 & rohmad & $\begin{array}{l}1 \text { makan-minum gratis di rumah } \\
\text { kandidat }\end{array}$ & $\begin{array}{l}1 \text { Benda pusaka batu merah } \\
\text { delima } \\
2 \text { keturanan lurah dari Orang } \\
\text { Tua }\end{array}$ \\
\hline
\end{tabular}

Sumber: Berdasarkan Hasil Wawancara dengan kelima Informan

Berdasarkan tabel diatas Artikel ini juga menemukan faktor selain sumber daya material yang membentuk politik di pedesaan Jawa khususnya desa Sitimerto. Misalnya, sumber kekuasaan politik non-material yang identik dengan sumber kekuasaan menurut budaya Jawa yang bersifat kekuasaan spiritual. Karena semua calon kepala desa baik di Sitimerto menggunakan sumber daya terkait dengan 
gagasan kekuasaan Jawa dari konsep kesakten (Anderson, 2000) dan sumber kekuasaan seseorang atau kelompok untuk memerintah berasal dari Tuhan, dewa, atau wahyu, kewenangan memerintah berasal dari kekuatan yang sakral (Andrain dalam Surbakti, 1992). Karena hampir semua calon kepala desa yang bertarung dalam kontestasi Pilkades Sitimerto, mengerahkan ilmu gaib atau menggunakan ilmu hikmah yang mereka miliki, atau setidaknya menyimpan pusaka, jimat, dukun, dan ziarah kubur (pesarean). Beberapa calon kepala desa mengklaim memiliki tanda kekuasaan Jawa berupa wahyu (ndaru) dan keturunan lurah (trah) untuk membantu meyakinkan kader dan mempengaruhi pemilih menjelang pemilihan kepala desa.

\section{Kondisi Nyata: Pemilih Desa Pragmatis dan Rasionalisasi Calon Kepala Desa Tentang Politik Uang}

Politik uang telah membuat masyarakat desa semakin pragmatis, seringkali calon pemilih yang menerima uang kebingungan dalam menentukan pilihan kepala desa. Hari (2017) menjelaskan kalau zaman orang tua dulu tanda kekuasaan memang pulung, tapi sekarang sudah menjadi puluk (cara orang makan dengan menggunakan tangan). Jadi yang berkuasa adalah bukan pulung tapi orang yang punya banyak uang. Hal ini sesuai dengan pendapat Agung (2017) zaman sekarang hakekat orang yang punya wibawa adalah yang mempunyai uang. Bahkan seringkali satu keluarga menerima uang dari beberapa calon kepala desa yang berbeda. Sehingga sebagian keluarga biasanya memilih calon kepala desa yang mampu memberikan politik uang terbesar. Di tengah gempuran politik uang tersebut, lantas mengakibatkan warga desa yang kemudian menentukan pilihannya tidak didasarkan atas hubungan kekerabatan dengan salah satu calon kepala desa. Hal cukup menarik terkait pengaruh hubungan keluarga dalam Pilkades, adalah berdasarkan pengakuan Rohmad (2017) sekarang di desa mengandalkan keluarga tidak bisa, yang paling berpengaruh itu uang. Karena jika ditotal jumlah keluarga itu 200 orang tetapi suara yang diperoleh saat Pilkades sangat kecil.

Dari penjelasan diatas, tidak bisa dimungkiri juga bahwa uang yang dibagikan itu cukup mempengaruhi pilihan warga desa, terutama yang secara nominal. Dengan kata lain, ketika sebuah keluarga memperoleh amplop uang dari beberapa calon kepala desa, dan diantaranya ada yang menjanjikan lebih jika terpilih 
menjadi kepala desa. Dalam istilah bahasa Jawa (kediri mataraman), seperti yang dijelaskan Rohmad (2017) tambahan uang disebut 'bandule, maka berpeluang besar dipilih saat pemilihan kepala desa. Sebaliknya, ketika seorang calon kepala desa tidak mengeluarkan uang untuk keperluan membeli suara, besar kemungkinan ia tidak akan diperhatikan dan tentu tidak akan memperoleh suara yang signifikan untuk memenangkan Pilkades. Karena berdasarkan data di lapangan setiap kepala keluarga ada yang mendapat uang sebesar 1 juta belum anak dan istrinya juga mendapatkan sendiri (Rohmad, 2017).

Dari penjelasan diatas, memahami money politics sebagai praktik pemberian uang atau barang atau memberi iming-iming sesuatu, kepada massa (voters) secara berkelompok atau individual, untuk mendapatkan keuntungan politis (political gain). Artinya, tindakan money politics itu dilakukan secara sadar oleh pelaku dan penerimanya. Namun, definisi ini kurang akurat ketika dipakai untuk menganalisis kasus seperti pembagian sembilan bahan pokok kepada masyarakat. Kalau motifnya adalah semata-mata untuk membantu masyarakat, tentunya pemberian itu bukan money politics. Tetapi bagaimana kalau sang pemberi memang tulus berniat membantu rakyat kecil, tetapi tetap mendapatkan political gain dari aktivitasnya itu. Seperti diungkapkan Basuki (2018) sebagai orang Jawa harus menanam kebaikan, tetapi saat menjelang pemilihan kepala desa harus ada uang. Jadi hanya bersikap baik saja atau tolong menolong dengan warga desa itu tidak ada hasilnya (suara dalam Pilkades).

Terkait fenomena dampak politik uang, Indra Ismawan (1999:5) menjelaskan belum adanya definisi money politics yang bisa menjadi acuan, seringkali membuat kita bingung untuk mengkategorikan sebuah peristiwa tergolong money politics atau bukan. Implikasinya, beberapa pihak dapat secara leluasa melakukan tindakan yang sebenarnya sudah menjurus pada money politics, tanpa bersedia dikatakan melakukan praktik money politics. Praktik money politics pada level nasional merupakan reproduksi atau agregasi kejadian pada scope yang lebih kecil dan terbatas. Kita bisa melihat money politics pada proses demokrasi pada tingkat yang paling rendah, misalnya pemilihan kepala desa (Pilkades). Para calon kepala desa acapkali mendadak jadi "sinterklas" menjelang hari pemungutan suara. Mereka membagi uang atau barang agar pilihan rakyat akan jatuh kepadanya. Tidak jarang seorang kepala desa harus mengeluarkan uang ratusan juta rupiah untuk meraih kemenangan dalam 
Pilkades. Para botoh (petaruh) ikut meramaikan atau justru memperkeruh situasi dengan pertaruhannya yang berbau perjudian. Kemungkinan besar, para botoh itu juga melakukan praktik money politics. Dalam mengomentari fenomena politik uang dan pemilih desa yang dianggap pragmatis, Agung (2017) mempunyai pandangan tidak menggunakan politik uang untuk memberikan pendidikan politik bagi masyarakat. Bahwa calon lurah tidak harus ditentukan dengan kekayaannya, supaya tidak dimonopoli orang kaya, dan menjadikan desa seperti kerajaan atau disebut dinasti politik. Untuk lebih jelas mendiskripsikan operasional pembagian politik uang oleh calon kepala desa Sitimerto maka dapat dilihat dalam gambar 2 di bawah ini.

\section{Gambar 2. Model Pembagian Politik Uang di Pilkades Tanjung}

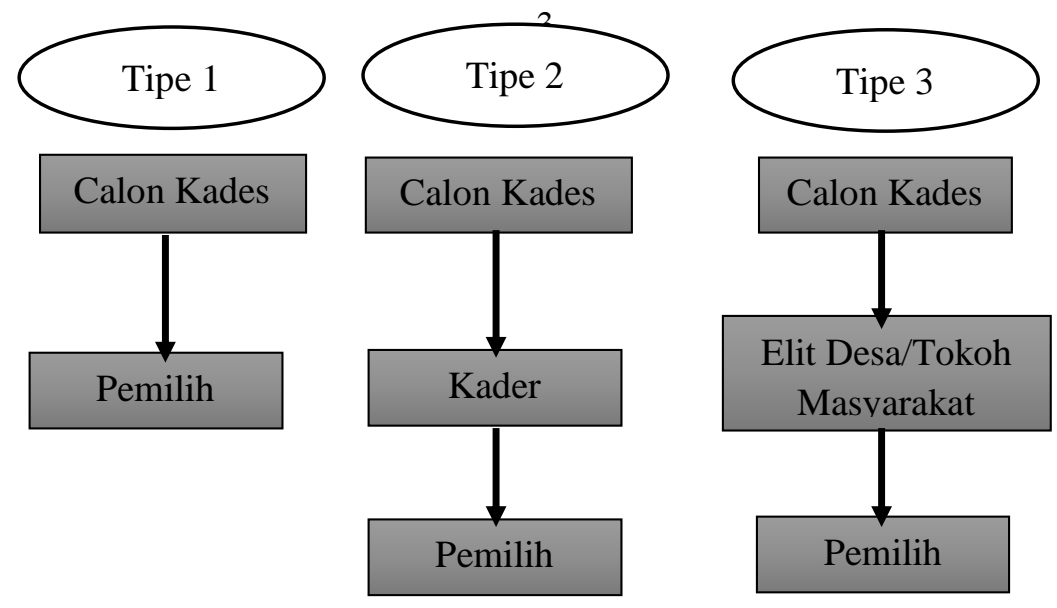

Sumber: berdasarkan observasi lapangan

Sementara itu, calon yang memilih strategi membeli suara dengan politik uang, mempunyai cara khusus untuk memastikan uang tersebut sampai kepada pemilih di desa Sitimerto. Menurut Adit (2017) menjelaskan biasanya calon kepala desa menyadari bahwa dari sejumlah uang yang didistribusikan itu, ada yang mungkin tidak sampai di tangan calon pemilih desa. Lantas, mereka berusaha semaksimalkan mungkin agar uang yang dibagikan tidak terjadi penyelewengan dan benar-benar diserahkan kepada calon pemilihnya, terutama daerah yang menjadi lumbung suara calon kepala desa tersebut. Para calon kepala desa kemudian menggunakan strategi yang cukup variatif untuk mengatasi masalah tersebut. Sebagai contoh, salah seorang calon kepala desa membagi tim sukses menjadi dua tugas; ada yang bertugas 
membagikan amplop dan sebagian lain bertugas untuk mengontrol proses distribusi uang. Misalnya, ketika pemilih sudah didatangi untuk pembagian amplop, maka pada besoknya didatangi tim sukses (kader lain yang berbeda) yang bertugas mengkonfirmasi sudah menerima uang atau tidak.

Sedangkan satu lawan politik lainya yang juga menggunakan strategi membeli suara dengan politik uang di desa Sitimerto, tetapi nominal masih kalah besar dari Adit. Berdasarkan pengakuan calon tersebut, Hari (2017) lebih fokus untuk menjadikan kader-kadernya lebih solid, untuk memantau pergerakan politik uang dari pihak pertahanan. Ia menjelaskan pada saat malam menjelang pemilihan kemarin sempat memergoki bapak kepala dusun (kasun) membantu proses distribusi uang dari pihak lawan yakni Adit. Sedangkan sebagai perangkat desa seharusnya diharapkan untuk bersikap netral tidak memihak kepada calon pertahanan. Pada saat memilih strategi politik uang sebenarnya informan Hari sudah merasa akan kalah dengan kekuatan ekonomi pihak keluarga pertahanan yang mengusung Adit.

\section{Kesimpulan}

Ditinjau perspektif teori oligarki dan elite, dalam konteks Pilkades Sitimerto kelompok oligarki berupaya sekaligus menjadi elite. Meskipun keunggulan sumber daya material oleh oligark Haji Mul yang mengutus putranya Adit telah mampu memenangkan pemilihan kepala desa. Namun, Haji Mul adalah oligark berupaya sekaligus menjadi elite agar bisa mengekploitasi sumber kekuasaan material dan non-material. Dengan itu, Adit putranya sebagai calon kepala desa dapat menggunakan sumber kekuasaan non-material yang identik dengan sumber kekuasaan menurut budaya Jawa, yakni 'kesakten' untuk mempengaruhi pemilih desa dengan pendekatan kultural.

Pemilih desa ketika menerima uang dari calon kepala desa, memaknai uang dengan rasionalisasi yang juga beragam, tidak hanya sebagai pertukaran jual-beli suara. Setidaknya, ada empat bentuk rasionalisasi makna uang yang dipahami oleh pemilih desa. Pertama, sebagian warga desa menganggap bahwa uang yang diterimanya itu sebagai rezeki. Kedua, sebagian warga uang pengganti datang ke tempat pemungutan suara. Oleh karena itu, meskipun tidak masuk kerja, para pemilih desa tetap mendapatkan penghasilan atau sebagai bentuk ganti rugi. Ketiga, sebagian 
warga desa memaknai uang sebagai bentuk keseriusan calon kepala desa untuk berkontestasi di Pilkades. sehingga pemilih desa cenderung memilih calon kepala desa yang mampu memberikan uang dalam amplop paling besar. Keempat, ada warga desa memaknai uang tersebut sebagai uang rakyat, sebagai bentuk kompensasi pilihan politiknya kepada calon kepala desa. Misalnya, konteks calon incumbent yang maju kembali untuk menjadi kepala desa, ada warga desa yang memaknai uang tersebut adalah uang rakyat desa yang sebelumnya diambil oleh para kandidat (terutama kandidat berasal dari pihak pertahanan incumbent) selama menjabat kepala desa, misalnya fasilitas tanah bengkok dan sumber-sumber keuangan yang dinikmati kepala desa selama menjabat.

\section{Daftar Rujukan}

\section{Buku}

Andrain, Charles F. (1992). Kehidupan Politik dan Perubahan Sosial. Yogyakarta: Tiara Wacana

Denzin, Norman K and Yvonna S. Lincoln. (2009). Handbook of Qualitative Research. (Terjemahan oleh Dariyatno, Badrus Samsul Fata, Abi, John Rinaldi), Yogyakarta: Pustaka Pelajar

Hadiz, Vedi R. (2005). Dinamika Kekuasaan: Ekonomi Politik Indonesia Pasca Soeharto. Jakarta: LP3ES . (2010). Localising Power in Post-authoritarian Indonesia A Southeast Asia Perpective. California: Stanford University Press

Ismawan, Indra. (1999). Monoy Politics Pengarub Uang dalam Pemilu. Yogyakata: Media Pressindo

Keller, Suzzane. (1995). Penguasa dan Kelompok Elit : Peranan Elit dalam Msyarakat Moderm (terj.), Jakarta : Rajawali Press

Michels, Robert. (1984), Partai Politik Kecenderungan Oligarkis dalam Birokrasi (Alih Bahasa:Mien Joebhaar), Jakarta: CV Rajawali

Surbakti, Ramlan. (2010). Memahami Ilmu Politik, Jakarta: Grasindo

Varma, SP. (2007). Teori Politik Modern, Jakarta: Rajawali Pers, Winters, Jeffey A. (2011). Oligarki. Jakarta: Gramedia Pustaka Tama. 


\section{Jurnal}

Ananta, Dicky D. (2016) Politik Oligarki dan Perampasan Tanah di Indonesia: Kasus Perampasan Tanah di Kabupaten Karawang Tahun 2014. Jurnal Politik Vol. 2, No. 1, Agustus 2016

Aspinall, Edward and Noor Rohman. (2017) Village Head Election in Java: Money Politics and Brokerage in The Remaking of Indonesia's Rural Elite. Journal of Southeast Asian Studies, 48(1), pp 31-52 February 2017

Cahyono, Heru. (2005). Konflik Elite Politik di Pedesaan: Relasi antara Badan Perwakilan Desa dan Pemerintahan Desa, Jurnal Penelitian Politik LIPI Vol 2, No 1, 2005

Faturahman, Burhanudin M. (2018). Aktualisasi Nilai Demokrasi Dalam Perekrutan dan Penjaringan Perangkat Desa. Jurnal Sospol, Vol. 4, No. 1 (Januari-Juni 2018),Hlm 132-148

Pribadi, Yanwar. (2015). The Klebun, The Kiai and The Blater: Note from western Madura, Indonesia. Journal South East Asia Research, 23,3, pp 303-317. http:// doi: $10.5367 / /$ sear.2015.0267

Robison, Richard. (1981). Culture, Politics and Economy in the Political History of The New Order. Cornell Southeast Asia Program, Ithaca, New York 31(23), April 1981

Yani Yuningsih, Neneng (2016). Demokrasi dalam Pemilihan Kepala Desa? Studi Kasus Desa Dengan Tipologi Tradisional, Transisional, dan Modern di Provinsi Jawa Barat Tahun 2008-2013. Jurnal Politik, Vol.1 No. 2 , Februari 2016

Winters, Jeffrey A. (2013). Oligarki dan Demokrasi di Indonesia. Dalam Majalah Prisma Vol. 33, No. 1, 2014

\section{Disertasi}

Bahar, Moh. Syaeful (2017). Interaksi Antara Kiai dan Bejingan Dalam Proses Pemiliban Kepala Desa (Pilkades) di Bondowoso: Studi Tentang Pola Hubungan Orang Kuat Lokal Pasca Orde Baru. Disertasi, Program Parcasarjana Universitas Airlangga, Surabaya.

Iberamsjah. (2002). Elit Desa Dalam Perubahan Politik: Kajian Kasus Pengambilan Keputusan di Desa Gede Pangrango Kecamatan Kadudampit, Kebupaten 
Sukabumi, Jawa Barat Pada Masa Awal Penerapan Otonomi Daerah 2000-

2001. Disertasi, Departemen Ilmu Politik Universitas Indonesia Jakarta.

\section{Undang-Undang dan Peraturan Pemerintah}

Peraturan Undang-Undang No. 6 Tahun 2014 Tentang Desa (Sub Bagian Pemilihan Kepala Desa Serentak)

\section{Wawancara}

Wawancara dengan Haji Mul (Kediri, Juli 2018)

Wawancara dengan Adit (Kediri, Agustus 2017)

Wawancara dengan Basuki (Kediri, Agustus 2017)

Wawancara dengan Hari (Kediri, Agustus 2017)

Wawancara dengan Agung (Kediri, Agustus 2017)

Wawancara dengan Rohmad (Kediri, Agustus 2017) 